\title{
Correlation Studies in Heliconia Genotypes
}

\author{
N. Santhosh*, S.Y. Chandrashekar and C. Vidya \\ Department of Floriculture and Landscape Architecture (FLA), College of Horticulture, \\ Mudigere, University of Agricultural and Horticultural Sciences, Shivamogga, India \\ *Corresponding author
}

\section{A B S T R A C T}

\begin{tabular}{|l|}
\hline Ke y w o r d s \\
Correlation, \\
Heliconia \\
Genotypes \\
\hline Article Info \\
\hline $\begin{array}{l}\text { Accepted: } \\
\text { 04 November } 2018 \\
\text { Available Online: } \\
\text { 10 December } 2018\end{array}$ \\
\hline
\end{tabular}

\section{Introduction}

Heliconias are popular landscape plant and cut flower crop grown for their attractive foliage and brilliant flower spikes in tropical and subtropical areas of the world. The showy part of spikes is the colourful bracts subtending the flowers. Heliconia are close relatives of gingers, bananas, bird of paradise, and traveller's palms. The natural variability in heliconia plants and populations is high (Berry and Kress, 1991), and can be exploited for breeding purposes. A large number of diverse genotypes are grown in different parts of India. But systematic studies regarding their flower quality and yield traits are negligible. A huge quantum of variability exists in this crop with respect to shape, size, growth habit, flowering behaviour, vase-life, etc. Present investigations were initiated to assess 14 selected Heliconia genotypes for morphological, flowering and vase life parameters to select suitable genotypes for further exploitation.

\section{Materials and Methods}

The experiment was conducted in the Department of Floriculture and Landscape Architecture, College of Horticulture, Mudigere, during the year 2016-2017 in RCBD with 3replications. The 14genotypes are Super Cheri, Lobster Claw II, Rostrata, Guyana, Lady Di, Daintree Red, Golden Yellow, African Dawn, Sassy, Distans, Tropics, Strawberry Cream, Golden Torch and 
Lobster Claw I. Uniform suckers of these genotypes were planted in plot with a spacing of $1 \mathrm{~m} \times 1 \mathrm{~m}$. Recommended cultural practices were followed as and when necessary. Observations were recorded on various morphological, flowering and vase life parameters from five random plants from each replication. Data were analysed as per Panse and Sukhatme (1967). Correlation analysis was carried out as per the formulae suggested by Fisher (1954).

\section{Results and Discussion}

Estimates of coefficient of correlation worked out at genotypic and phenotypic levels for 15 characters are presented in Tables 1 and 2 . The study revealed that the number of stalks produced per plant had significantly correlated in positive direction with number of shoots per plant, number of leaves per plant, leaf length, plant height, number of flowers per bract, leaf area, vase life and stalk length at both genotypic and phenotypic levels. This reveals that indirect selection of anyone of these characters shall lead to increase the cut flower yield. These findings are accordance with Nazia (2007) and Sheela et al., (2006) in heliconia and Rakeshkumar and Santoshkumar (2010 in snapdragon.

The plant height was significantly correlated in positive direction with leaf length, number of leaves per plant, spike width, leaf area, number of shoots per plant, spike length, leaf width, number of bract per spike, stalk length, number of stalks per plant, stalk girth and number of flowers per bract both at genotypic and phenotypic level. Similar results were reported by Sheela et al., (2006) and Dileep (2012) in heliconia and Vikas et al., (2011) in dahlia. However it showed non-significant correlation with other characters. This suggests that selection of these characters would be effective in improving total yield per plant.
The number of stalks per plant, number of leaves per plant, leaf length, plant height, leaf area, number of flowers per bract, stalk length, vase life, spike width, leaf width and stalk girth are significantly correlated with number of shoots per plant in positive direction at both genotypic and phenotypic levels. The number of leaves per plant showed significant positive correlation at both genotypic and phenotypic levels with plant height, number of shoots per plant, leaf length, number of stalks per plant, spike width, leaf area, number of flowers per bract, spike length, leaf width, and stalk length and Vase life had significant correlation in positive direction at genotypic level only. Similar results were found by Sheela et al., (2006) in heliconia and Angadi and Archana (2014) in bird of paradise. These results are in accordance with Kumar et al., (2011) in heliconia and Sahana (2010) in gladiolus.

The leaf length showed positively significant correlation with leaf area, plant height, spike width, number of shoots per plant, number of leaves per plant, leaf width, number of stalks per plant, spike length, stalk girth, number of flowers per bract, vase life, number of bracts per spike and stalk length at both genotypic and phenotypic level. The leaf width exhibited positively significant correlation at both genotypic and phenotypic levels with leaf area, stalk girth, vase life, leaf length, spike width, number of bracts per spike, plant height, days to emergence of spike, spike length, stalk length, number of shoots per plant, number of leaves per plant. The correlation with number of flowers per bract was positively significant at genotypic level. Similar trend was reported by Nazia (2007), Guimaraes et al., (2014) in heliconia and Angadi and Archana (2014) in bird of paradise.

The leaf area showed positive significant correlation with leaf width, leaf length, stalk girth, plant height, spike width, vase life, 
number of shoots per plant, number of leaves per plant, number of bracts per spike, spike length, days to emergence of spike, stalk length, number of stalks per plant and number of flowers per bract at both genotypic and phenotypic level. Similar findings are reported by Dileep (2012) in heliconia. Days to emergence of spike had positively significant correlation with leaf width, leaf area, stalk girth, number of bracts per spike at both genotypic and phenotypic level. The correlation with spike width had positive significant at genotypic level. Similar results were reported by Costa et al., (2007) in heliconia.

The stalk length had positively significant correlation at both genotypic and phenotypic levels with stalk girth, plant height, number of shoots per plant, leaf area, leaf width, leaf length, number of leaves per plant, number of bracts per spike, number of stalks per plant, spike length and number of flowers per bract. Genotypic and phenotypic correlation of stalk girth was significantly positive correlated with leaf width, leaf area, vase life, number of bracts per spike, leaf length, stalk length, plant height, spike width, days to emergence of spike, number of shoots per plant and spike length. The spike length had positively significant correlation with number of bracts per spike, spike width, plant height, leaf length, leaf area, leaf width, number of leaves per plant, stalk length, number of flowers per spike, stalk girth at both genotypic and phenotypic levels. Sheela et al., (2006) and Kumar et al., (2011) reported similar results in heliconia and Angadi and Archana (2014) in bird of paradise.

The number of bracts per spike was positively significant correlation with spike length, spike width, leaf width, leaf area, stalk girth, plant height, leaf length, stalk length and days to emergence of spike at both genotypic and phenotypic level. The number of flowers per bract exhibited significant and positive association with number of shoots per plant, number of leaves per plant, leaf length, number of stalks per plant, plant height, leaf area, vase life, spike length, stalk length and spike width at both genotypic and phenotypic level. It had positively significant correlation with leaf width at genotypic level. Genotypic and phenotypic correlation of vase lifewas positively significant correlated with stalk girth, leaf width, leaf area, leaf length, number of shoots per plant, number of stalks per plant, number of flowers per bract. The correlation with number of leaves per plant and spike width had positive significant at genotypic level. These results are in accordance with Sheela et al., (2006) in heliconia and Angadi and Archana (2014) in bird of paradise.

The summary and conclusion are given below:

Knowledge regarding the association of various characters among themselves and with economic characters is necessary for making indirect selection for improvement of economic characters. The expression of a character in a plant is the consequence of a chain of inter-relationships between characters either directly or through other events. Character association as correlation is a measure of the degree of association between two characters. Correlation studies paved way to know the association prevailing between highly heritable characters with most economic and gives better understanding of the contribution of each trait building up of the genetic makeup of the crop. The phenotypic relationship between two characters. This does not give true genetic picture of the relationship because it includes both heritable and nonheritable association. Genotypic correlations provide an estimate of inherent association between genes controlling any two characters. Hence it is of greater significance and could be effectively utilised in formulating an effective selection scheme. 
Table.1 Genotypic correlation coefficient for growth, flowering, quality and yield characters in heliconia genotypes

\begin{tabular}{|c|c|c|c|c|c|c|c|c|c|c|c|c|c|c|c|}
\hline & 1 & 2 & 3 & 4 & 5 & 6 & 7 & 8 & 9 & 10 & 11 & 12 & 13 & 14 & 15 \\
\hline 1 & 1.000 & $0.757 * *$ & $0.854 * *$ & $0.880 * *$ & $0.607 * *$ & $0.774 * *$ & 0.243 & $0.532 * *$ & $0.449 * *$ & $0.714 * *$ & $0.836 * *$ & $0.537 * *$ & $0.447 * *$ & 0.219 & $0.502 * *$ \\
\hline 2 & & 1.000 & $0.920 * *$ & $0.831 * *$ & $0.439 * *$ & $0.655^{* *}$ & -0.063 & $0.510 * *$ & $0.350^{*}$ & 0.209 & $0.455^{* *}$ & 0.049 & $0.579 * *$ & $0.462 * *$ & $0.961 * *$ \\
\hline 3 & & & 1.000 & $0.808 * *$ & $0.414 * *$ & $0.614^{* *}$ & 0.001 & $0.408 * *$ & 0.271 & $0.431 * *$ & $0.677^{*} *$ & 0.219 & $0.579 * *$ & $0.328^{*}$ & $0.784^{* *}$ \\
\hline 4 & & & & 1.000 & $0.755^{* *}$ & $0.922 * *$ & 0.298 & $0.408 * *$ & $0.575 * *$ & $0.589 * *$ & $0.835 * *$ & $0.481 * *$ & $0.571 * *$ & $0.491 * *$ & $0.590 * *$ \\
\hline 5 & & & & & 1.000 & $0.945^{* *}$ & $0.553 * *$ & $0.442 * *$ & $0.945 * *$ & $0.454 * *$ & $0.641 * *$ & $0.622 * *$ & $0.305^{*}$ & $0.766 * *$ & 0.282 \\
\hline 6 & & & & & & 1.000 & $0.469 * *$ & $0.453 * *$ & $0.837 * *$ & $0.535 * *$ & $0.772 * *$ & $0.586 * *$ & $0.433 * *$ & $0.693 * *$ & $0.448 * *$ \\
\hline 7 & & & & & & & 1.000 & -0.158 & $0.426 * *$ & $0.295^{* *}$ & $0.328 *$ & $0.337 *$ & -0.173 & 0.223 & -0.154 \\
\hline 8 & & & & & & & & 1.000 & $0.565 * *$ & $0.383^{*}$ & 0.167 & $0.411 * *$ & $0.370 *$ & 0.280 & $0.405^{* *}$ \\
\hline 9 & & & & & & & & & 1.000 & $0.341 *$ & $0.449 * *$ & $0.575^{* *}$ & 0.303 & $0.828 * *$ & 0.230 \\
\hline 10 & & & & & & & & & & 1.000 & $0.721 * *$ & $0.927 * *$ & $0.376^{*}$ & -0.044 & -0.061 \\
\hline 11 & & & & & & & & & & & 1.000 & $0.661 * *$ & $0.309 *$ & $0.315^{*}$ & 0.180 \\
\hline 12 & & & & & & & & & & & & 1.000 & 0.267 & 0.172 & -0.205 \\
\hline 13 & & & & & & & & & & & & & 1.000 & $0.400 * *$ & $0.476^{* *}$ \\
\hline 14 & & & & & & & & & & & & & & 1.000 & $0.425^{* *}$ \\
\hline 15 & & & & & & & & & & & & & & & 1.000 \\
\hline
\end{tabular}

*Significant at $\mathrm{p}=0.05$ probability $(0.304)$

1. Plant height $(\mathrm{cm})$

2. Number of shoots per plant

3. Number of leaves per plant

4. Leaf length $(\mathrm{cm})$

5. Leaf width $(\mathrm{cm})$
** Significant at $\mathrm{p}=0.01$ probability $(0.393)$

6. Leaf area $\left(\mathrm{cm}^{2}\right)$

7. Days to emergence of spike

8. Stalk length $(\mathrm{cm})$

9. Stalk girth $(\mathrm{mm})$

10. Spike length $(\mathrm{cm})$
11. Spike width $(\mathrm{cm})$

12. Number of bracts per spike

13. Number of flowers per bract

14. Vase life (days)

15. Number of stalks per plant 
Table.2 Phenotypic correlation coefficient for growth, flowering, quality and yield characters in heliconia genotypes

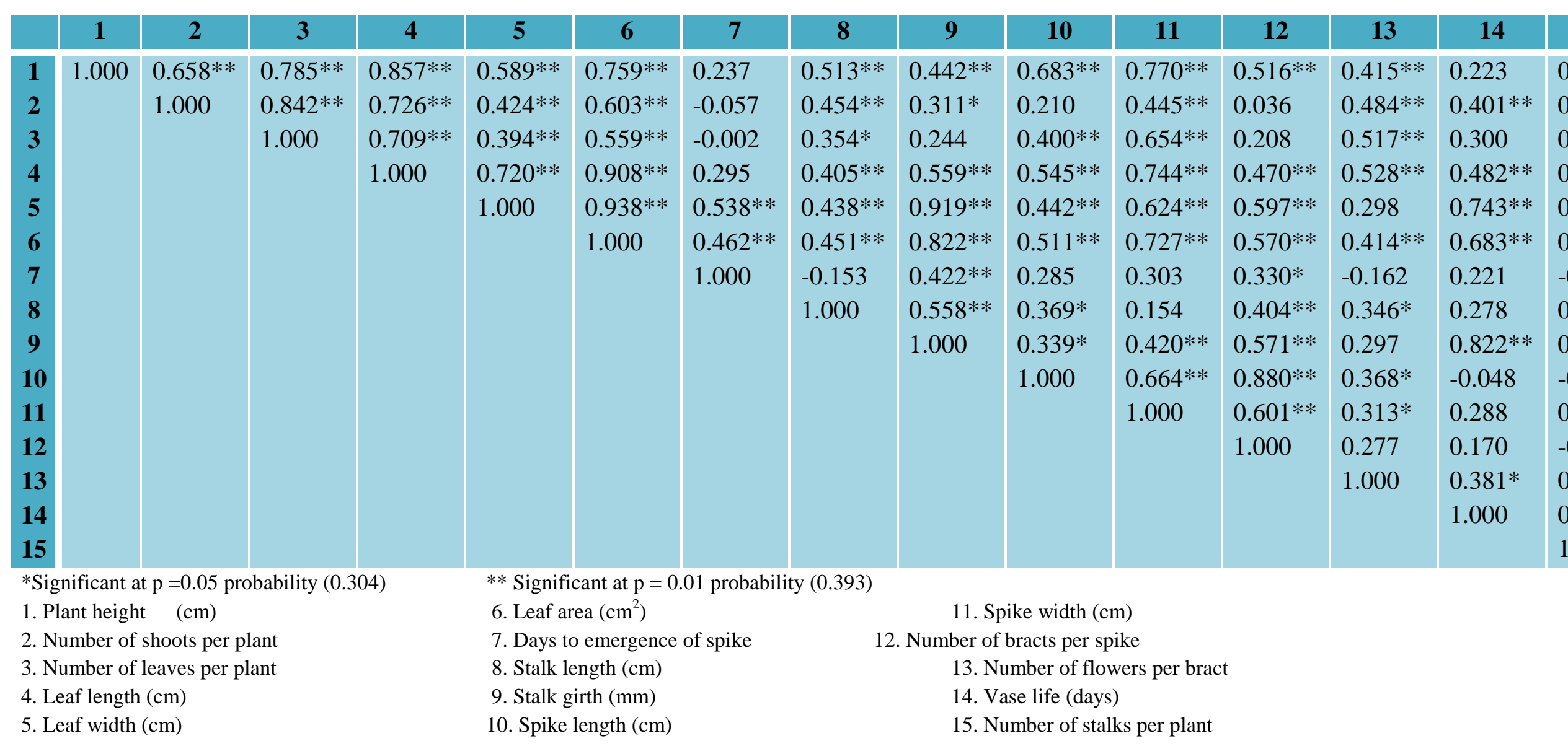


The number of flowers per bract exhibited significant and positive association with number of shoots per plant, number of leaves per plant, leaf length, number of stalks per plant, plant height, leaf area, vase life, spike length, stalk length and spike width at both genotypic and phenotypic level. It had positively significant correlation with leaf width at genotypic level.

Genotypic and phenotypic correlation of vase life was positively significant correlated with stalk girth, leaf width, leaf area, leaf length, number of shoots per plant, number of stalks per plant, number of flowers per bract. The correlation with number of leaves per plant and spike width had positive significant at genotypic level.

The number of stalks produced per plant had significantly correlated in positive direction with number of shots per plant, number of leaves per plant, leaf length, plant height, number of flowers per bract, leaf area, vase life and stalk length at both genotypic and phenotypic level.

Results of the experiment have clearly confirmed that, cultivar Tropics found to be superior with respect to most of traits such as vegetative, flowering, yield and quality parameters. Hence, its commercial cultivation can be taken up in hill zone of Karnataka, followed by Golden Torch and Sassy (Plate 4).

Though the initial investment for cultivation of heliconia under shade house is relatively low, it is profitable to grow it under shade house condition. The economics was worked out in the study indicated $\mathrm{B}$ : $\mathrm{C}$ ratios ranging from 0.90 to 5.47 for the various genotypes. Most of the flowers produced in shade house were of grade I quality (Blue) and fetched good price in the both domestic and international market.

\section{References}

Angadi, A.P. and Archana, B., 2014, Genetic variability and correlation studies in bird of paradise genotypes for flower and yield parameters during 2011. Bioscan., 9(1):385-388.

Berry, F and Kress, W. J., 1991, Heliconia: an identification guide. Smoithsonian Institute press, Washington and London, pp:334.

Dileep, N. N., 2012, Variability and character association in heliconia (Heliconia spp). M. Sc. (Hort.) Thesis, Kerala Agric. Univ., Kerala (India).

Fisher, R. A., 1918, The correlation between relatives on the supposition of Mendelian inheritance. Trans. Roy. Soc., Edinburgh, 52: 399-483.

Guimaraes, W. N. R., Martins, L. S. S., Castro, C. F. F., Filho, J. L. S. C., and Loges, V., 2014, Heliconia phenotypic diversity based on qualitative descriptors. Genet. Mol. Res., 13(2): 3128-3142.

Kuamar, P. P., Janakiram, T., Kumar, D. P. and Venugopaln, R., 2011, Correlation studies in Heliconia genotypes. J. Orn. Hort., 14(1\&2):21-23.

Nazia, S., 2007. Genetic variability studies in heliconia genotypes (Heliconia spp.). M. Sc. (Hort.)thesis, Univ. Agric. Sci., Dharwad, Karnataka (India).

Nazia, S., Reddy, B. S. and Kulkarni, B. S., 2014, Variability studies in Heliconia (Heliconia spp.). J. Flori., 2(2): 71-73.

Panse, V. G. AND SUKHATME, P. V., 1967, Statistical Methods for Agricultural Workers, ICAR. New Delhi.

Sahana, K., 2010, Studies on genetic variability in gladiolus (Gladiolus grandiflorum L.). M. Sc. (Hort.) Thesis, Univ. Agric. Sci., Dharwad, Karnataka (India).

Sheela, V. L., Nair, C. S. J., Rakhi, R., Lekshmi, P. R. G., 2006, Correlation 
studies in heliconia. J. Orn. Hort., 9(1): 29-32.

Vikas, H. M., Patil, V. S. and Dorajeerao, A. V. D., 2015, Evaluation of dahlia genotypes based on vegetative and quality characters. Pl. Archs., 15(1): 283-286.

\section{How to cite this article:}

Santhosh, N., S.Y. Chandrashekar and Vidya, C. 2018. Correlation Studies in Heliconia Genotypes. Int.J.Curr.Microbiol.App.Sci. 7(12): 329-335.

doi: https://doi.org/10.20546/ijcmas.2018.712.040 